\title{
ФОРМУВАННЯ ІНКЛЮЗИВНОЇ КОМПЕТЕНТНОСТІ МАЙБУТНІХ УЧИТЕЛІВ ЯК ОСНОВИ ДУХОВНОГО РОЗВИТКУ СУСПІЛЬСТВА
}

\author{
Ткаченко Л. П. \\ доктор педагогічних наук, доцент, завідувач кафедри теорії і методики \\ викладання філологічних дисциплін у дошкільній, початковій і спеціальній освіті, \\ Харківський національний педагогічний університет \\ імені Г. С. Сковороди, м. Харків, Україна
}

У статті йдеться про шляхи формування інклюзивної компетентності майбутніх учителів, як важливого не лише професійного показника, а й чинника розбудови громадянського суспільства. Доведено, щуо існує низка суперечностей щуодо запровадження інклюзивного навчання в практику нової української школи, які потребують нагального вирішення.

Ключові слова: інклюзія, компетентність, школа, учні, суспільство, гуманізація.

The article discusses the ways of forming inclusive competence of future teachers as an important not only professional indicator, but also a factor in the development of civil society. It is proved that there are a number of contradictions regarding the introduction of inclusive education in the practice of the new Ukrainian school, which need to be urgently resolved.

Key words: inclusion, competence, school, students, society, humanization.

Якісні зміни в системі освіти України означено цілою низкою нових реалій. Однією з таких стало запровадження інклюзивного навчання у практику закладів загальної середньої освіти та підготовки вчителя до роботи в інклюзивному середовищі. Професійний стандарт визначає інклюзивну компетентність як «здатність створювати умови що забезпечують функціонування інклюзивного освітнього середовища, здатність до педагогічної підтримки осіб з особливими освітніми потребами, здатність забезпечувати в освітньому середовищі сприятливі умови для кожного учня, залежно від його індивідуальних потреб, можливостей, здібностей та інтересів» [1]. Цілком зрозуміло, що освітні програми підготовки майбутніх учителів містять дисципліни які забезпечують формування інклюзивної компетентності. Разом із тим на робочому місці молодий учитель стикається з купою проблем, 
Розділ І. Ціннісні орієнтири духовно-інтелектуального виховання, розвиток духовно-інтелектуальних якостей особистості в умовах співпраці й інклюзії

пов'язаних з реалізацією цієї компетентності: від організації комфортного освітнього середовища до забезпечення конкретної індивідуальної траєкторії супроводу учня з особливими освітніми потребами. На підставі цього можемо констатувати, що сьогодні виникла низка суперечностей, які вимагають нагального вирішення: між декларуванням необхідності запровадження інклюзивного навчання у практику школи та недостатньою підтримкою таких форм роботи з боку адміністративного ресурсу всіх рівнів; між потребою кваліфікованого супроводу учнів $з$ особливими освітніми потребами та обмеженими можливостями закладу освіти (штатні приписи, відсутність асистентів учителя, недостатність навчально-методичного супроводу); між усвідомленням необхідності запровадження інклюзивного навчання та певними стереотипами, що роками складалися в суспільстві; між потребою забезпечення рівного доступу до навчання всім дітям та недостатньою розробленістю відповідної діагностики, що забезпечить оптимальні варіанти цього навчання. Отже, у процесі підготовки майбутнього вчителя необхідно враховувати названі суперечності, у якості напрямів для наукового пошуку, тем для методичних розробок, аналізу подібної проблематики під час педагогічних практик.

Однією з найбільших, на нашу думку, проблем є стереотипність мислення пересічних громадян, які формують загальну думку про інклюзивну освіту та суттєво впливають на активність запровадження іiі в практику нової української школи. Сьогодні назріла потреба у відкритій суспільній дискусії щодо запровадження інклюзивного навчання. Аналіз педагогічного досвіду, бесіди з учителями, батьками, дітьми доводять, що існує певна упередженість, побоювання, незручності під час навчання дитини з особливими освітніми потребами у звичайному класі. Так, переважна більшість сімей (57 \%) обирають індивідуальне навчання в звичайній школі, 22 \% сімей надають переваги спеціалізованим закладам навчання, 11 \% звернуться до приватних педагогів, у $10 \%$ сімей навчанням дитини займається один із батьків. Позитивним аспектом вважаємо появу ресурсних центрів, які враховують запити сімей, що мають дітей з різними нозологіями та кваліфікованих фахівців, які можуть ефективно працювати 3 такими дітьми. Разом 3 тим, зауважимо, що ресурсні центри створюються силами самих батьків, громадських організацій, волонтерів, фахівців, які опікуються відповідною проблематикою. 
Незаперечним є той факт, що необхідно посилити увагу до підтримки ефективного інклюзивного навчання з боку держави, особливо в частині підготовки майбутніх учителів та фахівців спеціальної освіти (асистентів учителя, логопедів, олігофренопедагогів, дефектологів, реабілітологів, учителів початкових класів, що володіють спеціальними методиками навчання). У процесі підготовки доцільно реалізовувати дуальну освіту на базі закладів освіти з інклюзивними класами. Майбутні учителі мають бути залучені до вивчення організації безпечного освітнього середовища, володіти методиками здоров $\square$ язбереження, спеціальними технологіями навчання. Важливим складником формування інклюзивної компетентності майбутніх учителів має стати проєктна та дослідницька робота, що дасть їм змогу напрацювати власний досвід, створити алгоритми взаємодії з учнями та їх батьками, ще під час навчання накопичити теоретичний та практичний досвід роботи в інклюзивному середовищі.

Отже, формування інклюзивної компетентності майбутнього вчителя полягає не лише у формуванні відповідних здатностей, а й у готовності здійснювати просвітницьку роботу, формувати позитивний імідж нової української школи, як школи рівного доступу до освіти всіх дітей, зокрема з особливими освітніми потребами.

\section{Список використаних джерел:}

1. Професійний стандарт за професіями «Вчитель початкових класів закладу загальної середньої освіти», «Вчитель загальної середньої освіти», «Вчитель 3 початкової освіти (з дипломом молодшого спеціаліста)» URL: https://mon.gov.ua/ua/news/zatverdzheno-profstandart-vchitelya-pochatkovihklasiv-vchitelya-zakladu-zagalnoyi-serednoyi-osviti-i-vchitelya-zpochatkovoyi-osviti (дата зверення: 09.10.2021). 